\title{
The Effect of Quantity and Quality Sustainability Disclosure Towards Innate and Discretionary Earnings Quality
}

\author{
Aditya Septiani ${ }^{1 *}$, Etna Yuyetta $^{2}$ \\ ${ }^{1}$ Accounting Department Faculty Economics and Business Diponegoro University, Indonesia \\ ${ }^{2}$ Accounting Department Faculty Economics and Business Diponegoro University, Indonesia
}

\begin{abstract}
Examining the effect of quantity and quality of sustainability disclosure on innate and discretionary earnings quality is the purpose of this research. the GRI G4 index was used to measure The sustainability disclosure quantity, while the report form, the adherence level and external statements was used to measure the quality of sustainability disclosure. A modified Jones Model uses to measure Innate and discretionary earnings quality as the dependent variable. Return on assets, leverage, net operating assets, and operating cycle were used as control variables. The research sample consisted of 10 main sector companies, namely the agriculture and mining sub-sectors, which are listed in the Indonesia Stock Exchange in 2014-2018. purposive sampling method was used in this research. The technique of analysis in this research is multiple linear regression analysis. As results, innate earnings quality was significantly influenced by sustainability disclosure quantity while discretionary earnings quality was not significantly influenced by sustainability disclosure quantity. Moreover, both innate earnings quality and discretionary earnings quality was significanty influenced by the quality of sustainability disclosure.
\end{abstract}

Keywords: quantity of sustainability disclosure, quality of sustainability disclosure, innate earnings quality, discretionary earnings quality

\section{Background}

Earning is an indicator of health and company performance that is used as a basis for decision making by stakeholders. The ability of earnings to reflect accuracy and predict future earnings is called earnings quality[8]. Conflicts of interest and knowledge gaps between agents and principals cause management to behave opportunistically with earnings management. Cases of earnings management that have occurred include the largest energy company in the United States, Enron, which with Arthur Andersen was proven to manipulate profits of 393 million US dollars while losing 644 million US dollars and

\footnotetext{
* Corresponding author: adityaseptiani24@students.undip.ac.id
} 
ultimately lost 74 billion stakeholders. No exception was occured in Indonesia, one of the state-owned drug producers, PT Kimia Farma,results a net profit of $24.7 \%$ and the same thing was done by PT Kaltim Prima Coal to cause underpayment of 1.5 trillion rupiah in taxes[25].

Earnings management practices affect earnings quality directly. High earning quality will reduce uncertainty, however, low earnings quality will cause information asymmetry towards users of financial statements[1].According to Francis, Olsson, \& Schipper (2008) [10]there are two factors that influence earnings quality. Firstly : a factor that reflects the innate features of the business model and operating environment called innate earnings quality. Secondly : the factor that reflects the financial reporting process itself, which is called discretionary earnings quality. Innate earnings quality refers to whether high-quality corporate business, how business models can convert income into cash and profits, while discretionary earnings quality leads to whether accounting can encourage clarity, communication, transparency, predictability, and visibility[7]. Discretionary earnings quality is indicator of earnings management.

Inline with the times and global issues, stakeholders are more interested in non-financial information, namely disclosure of sustainability[4]. Disclosure of sustainability information in Indonesia is still voluntary so management must consider completion and quality of disclosure. Information regarding this flexibility is information asymmetry. The flexibility of disclosure can be related to the amount of information delivered (quantity) and how information is received or given (quality). According to the theory of voluntary disclosure and signaling theory, companies are better when explain sustainability information and give signals to the public. Meanwhile, according to the theory of legitimacy, the disclosure of sustainability regarding bad results from bad companies must be done with bad finance.

Various studies have been conducted relating to the disclosure of sustainability to the quality of innate and discretionary income (see for example [14-17]), but the findings were still unconsistent. It is suggested to do further study the consistency of the findings if they are applied to different needs. Disclosure of sustainability to the quality of default and discretionary income. The aims of this study are analyzing and finding empirical evidence related to the effect of quantity and quality of sustainability disclosure on innate and discretionary earnings quality.

\section{Theoritical Framework and Hypothesis Development}

Sustainability disclosure is issued with the aim of providing information about company performance related to sustainability which is considered to better describe the company's prospects in the future. Because the nature of the disclosure is still voluntary, management has flexibility in determining how much (quantity) and how well (quality) the sustainability information is presented. Management has several motives for disclosing sustainability information and generally aims to attract investors or reduce negative impacts. This will be reflected in earnings quality, namely innate earnings quality which refers to the company's business quality and discretionary earnings quality which refers to management decisions.

In this research, the sustainability disclosure quantity and sustainability disclosure quality variables are used to influence innate earnings quality and discretionary earnings quality. Based on the voluntary disclosure theory, signaling theory, agency theory, and signaling theory, a framework of thought was developed which later became the hypothesis of this research. Those can be seen in Figure 1 


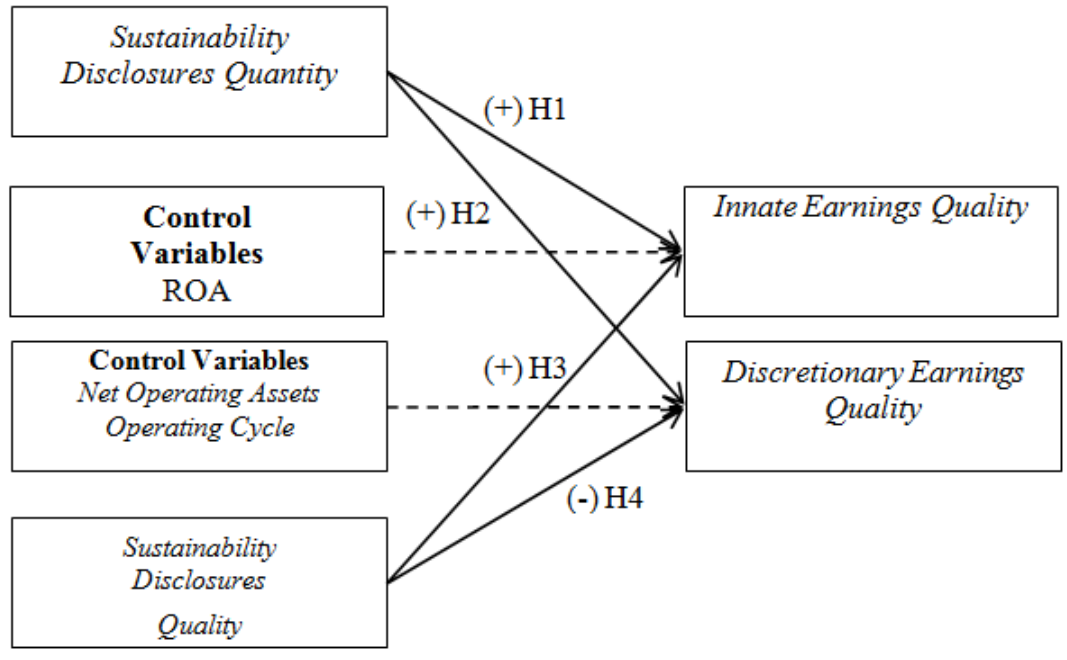

Figure 1.Theoritical Framework

\subsection{Effect of Quantity Disclosure Sustainability on Innate Earnings Quality}

Based on voluntary disclosure theory, companies tend to disclose all the information needed to ensure that the functioning of the capital market runs well. Sustainability disclosure is carried out in order to provide relevant information related to information on economic performance, the environment, and company compliance, which is a source of innate earnings quality. This is supported by the statement of signaling theory that the company will give a signal to the market with the aim of differentiating themselves from other competitors. The more items disclosed the more good signals the company wants to convey to the market are assumed. Furthermore, the market can respond to good signals given by the company. Thus, the more sustainability information disclosed (sustainability sustainability disclosure quantity) will further improve the quality of corporate earnings (innate earnings quality).

The effect of sustainability disclosure quantity on innate earnings quality is supported by research conducted by Francis, Nanda, et al. (2008)[9] who found that companies with good earnings quality tended to have larger voluntary disclosure. Kangarlouei et al. (2013) [14] also states that the higher voluntary disclosure can improve the quality of corporate profits. Bona-Sánchez et al. (2017)[2] which states that communication through sustainability disclosure will increase earnings informativeness so that stakeholders can interpret company information better. Based on the description, Hypothesis was developed as:

\section{H1: Sustainability disclosure quantity has a positive effect on innate earnings quality}

\subsection{Effect of Quantity Disclosure Sustainability on Discretionary Earnings Quality}

Based on voluntary disclosure theory, companies tend to disclose sustainability information with the aim of reducing information asymmetry between management and stakeholders which directly also suppresses the opportunistic behavior of management to present biased information. The more information disclosed by the company will increase knowledge and 
information about the company to stakeholders so that information inequality can be reduced and earnings quality for better. This is also strengthen by signaling theory which states that companies will try to provide information in order to give a good signal to the market. Therefore, the more items disclosed in the sustainability report (quantity sustainability disclosure) will be able to reduce the information asymmetry so that it can suppress earnings management actions that are reflected in better discretionary earnings quality.

The positive effect of sustainability disclosure quantity on discretionary earnings quality is consistent with research conducted by Lee (2017)[16] which states that sustainability information will improve the accuracy of earnings forecasts and tend to suppress managerial manipulation and opportunistic behavior. Similar research was also conducted by Dhaliwal, Li, Tsang, \& Yang (2011)[6] who found that companies with good performance tended to disclose more financial and non-financial information to the market so that they could reduce errors and forecast dispersion. This is also supported by $\mathrm{Ng} \&$ Rezaee (2015)[18] which states that management uses its discretion to communicate sustainability information to distinguish companies that have good sustainability performance from companies that have poor performance. Based on this description, hyphotesis is developed as:

\section{H2: The quantity of sustainability disclosure has a positive effect on discretionary earnings quality}

\subsection{The Effect of Sustainability Disclosure Quality on Innate Earnings Quality}

The quality of sustainability disclosures can further improve company operations through the creation of good quality sustainability disclosures. The quality of sustainability disclosure can also affect the perceptions and behavior of investors and financial analysts (Short, 2009)[19] . Knowing that the company is well prepared for sustainability reports, will attract investors to invest their capital. This also helps management in evaluate and improve sustainability performance. This statement is supported by the theory of voluntary disclosure and signaling theory which states that companies tend to reveal good information or signals so that they can be responded well by the market.

The positive influence of sustainability disclosure quality on innate earnings quality is supported by research by Mouselli, Jaafar, \& Hussainey (2012)[19] who found that there is a positive relationship between accruals quality and disclosure quality where the better the disclosure quality will have higher accruals quality. A similar study was conducted by Jiao \& Francis (2015)[13] who found a positive correlation between disclosure quality and future earnings forecasts. Mohammadi (2017)[18]also revealed that there is a relationship between the quality of disclosure and company performance now and company performance in the future. Based on this description, hyphotesis is developed as follows:

\section{H3: Sustainability disclosure quality has a positive effect on innate earnings quality}

\subsection{The Effect of Sustainability Disclosure Quality on Discretionary Earnings Quality}

Based on agency theory, the setting of high standards for sustainability disclosure quality can increase supervision and limits for management in making sustainability reports to reduce earnings management and other opportunistic behavior. Based on legitimacy theory, companies that disclose high quality sustainability information tend to have moral motivation to comply with social values and norms so that the company is less likely to engage in earnings management practices. Thus, companies with the implementation of 
high quality sustainability disclosure will be able to suppress earnings management actions so as to affect discretionary earnings quality better.

The positive influence between the quality of sustainability disclosure on discretionary earnings quality is in accordance with research conducted by Lobo (2001)[17] which states that disclosure quality has a significant negative correlation with earnings management, which means better discretionary earnings quality. Chamangard, Abadi, \& Janani (2013)[3] stated that there is a negative relationship between the quality of company disclosure and earnings management because improvement in disclosure quality will reduce information asymmetry that causes ambiguity in the firm's default value so that discretionary earnings quality increases. Based on this description, hyphotesis is developed as follows :

\section{H4: Sustainability disclosure quality has a positive effect on discretionary earnings quality}

\section{Method}

\subsection{Measurement of variables}

Innate earnings quality is earnings quality that reflects the innate features of the business model and corporate environment, whether the company's business is of high quality, how business models can convert revenue into cash and profits. Examples included in innate earnings quality are the business model, operating risk and operating environment. Discretionary earnings quality is earnings quality that reflects the financial reporting process and leads to whether accounting can encourage clarity, communication, transparency, predictability, and visibility. Discretionary earnings quality is earnings quality outside those included in innate earnings quality. Examples included in discretionary earnings quality are management decisions, auditing, compliance structures, regulations and standards.

To measure innate earnings quality and discretionary earnings quality, this study uses a modified Jones Model. Innate earnings quality value is the predicted value of the regression model above. The higher the predicted value from the Jones Model calculation, the higher the value of innate earnings quality. While discretionary earnings quality is the residual value of earnings quality measurements using the modified Model Jones approach as in the measurement of innate earnings quality variables. The lower the residual value of earnings Jones Model calculations, the higher the discretionary earnings quality and is considered to have low earnings management.

$$
\frac{T A C C_{i t}}{A_{i t-1}}=\alpha_{0} \frac{1}{A_{i t-1}}+\alpha_{1} \frac{\Delta R E V_{i t}-\Delta R E C_{i t}}{A_{i t-1}}+\alpha_{2} \frac{P P E_{i t}}{A_{i t-1}}+\alpha_{3} \text { ROAit }+\varepsilon_{i t}
$$

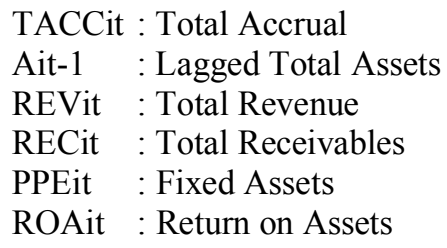

The quantity of sustainability disclosure is how many items of sustainability information are disclosed in the sustainability report. The measurement of sustainability disclosure quantity is based on the latest standard published by Global Reporting Initiatives, GRI G4. GRI G4 has two types of disclosures namely general and specific disclosures. 
General disclosure consists of seven parts, and specific disclosure consists of management approach and three performance indicators namely economic, environmental and social. Companies that disclose each item will be given a score of 1 while those who do not disclose will be given a score of 0 . The higher the number of scores, the higher the quantity of sustainability disclosure. Items disclosed by the company can be seen through the GRI index list of company sustainability reports.

The quality of sustainability disclosure is how management prepares a sustainability report. Measurement of the quality of sustainability disclosure uses three types of measurements, namely disclosure standards, the level of compliance and the presence or absence of assurance statements. Each report will be given a score based on criteria for the form and content of the report where the higher the total score obtained, the higher the quality of disclosure sustainability. The use of standards, the level of compliance and the availability of assurance statements can be identified through the status of the sustainability report on the GRI database website or can be directly checked in the company's sustainability report where it is explicitly disclosed in the sustainability report.

Table 1. Disclosures Item GRI 4

\begin{tabular}{|c|c|}
\hline Disclosures & Total \\
\hline \multicolumn{2}{|c|}{ General Standard Disclosures } \\
\hline Strategy and Analysis & 2 \\
\hline Organizational Profile & 14 \\
\hline Identified Material Aspects and Limits & 7 \\
\hline Stakeholder Approach & 4 \\
\hline Profile Report & 6 \\
\hline Adherence & 22 \\
\hline \multirow[t]{2}{*}{ Ethics and Integrity } & 3 \\
\hline & 58 \\
\hline \multicolumn{2}{|c|}{ Spesific Standards Disclosure } \\
\hline Management Approach & 1 \\
\hline \multicolumn{2}{|l|}{ Indicator: } \\
\hline The economy & 9 \\
\hline Environment & 34 \\
\hline \multirow[t]{2}{*}{ Social } & 48 \\
\hline & 92 \\
\hline Total & 150 \\
\hline
\end{tabular}


Table 2. Sustainability Disclosure Quality Measurement

\begin{tabular}{cc}
\hline Quality Measurement & NILAI \\
Measurement Standard & \\
Non-GRI & 0 \\
Citing GRI & 1 \\
GRI G1 & 2 \\
GRI G2 & 3 \\
GRI G3 & 4 \\
GRI G3.1 & 5 \\
GRI G4 & 6 \\
GRI Standards & 7 \\
Adherence Level & \\
None & 0 \\
GRI-Referenced & 1 \\
Cndeclared/Content Index Only & 2 \\
B & 3 \\
In Accordance & 4 \\
A & 5 \\
In Accordance-Core & 6 \\
Assurance Statement & 7 \\
Yes & 8 \\
No & 1 \\
\hline
\end{tabular}

ROA, Leverage, NOA, and Operating Cycle are used as control variable. ROA is the company's ability to generate profits that are calculated by dividing net income by total assets. Leverage is used to determine the extent of the company's assets financed by debt by dividing total liabilities by total assets. NOA (Net Operating Assets) is a business operating asset minus operating liabilities at the beginning of last year compared to sales at the beginning of the year which is a proxy for manager's decision. The operating cycle is used to measure the flexibility of a company's accounting system by calculating accounts receivable turnover plus inventory turnover and minus debt turnover.

\subsection{Sampling Method}

The population of this study are all companies included in the agricultural and mining subsectors listed on the Indonesia Stock Exchange in 2014-2018. This population was chosen because the company is very related to environmental issues so that more disclosure of sustainability and these two sub-sectors are major contributors to the ISHG. While the sample selection in this study is by purposive sampling, which is selecting samples from the population based on the following criteria: 
1. IDX listing companies included in the agriculture and mining sub-sectors

2. Companies that issue sustainability reports for 2014-2018

3. Companies that issued 2014-2018 financial statements

\subsection{Analysis Method}

Hypothesis testing is done by multiple linear regression analysis with the following regression models:

$\begin{array}{ll}\text { IEQ }=\beta_{0}+\beta_{1} \text { SD_Quan }+\beta_{2} \text { SD_Qual }+\beta_{3} \text { ROA }+ \\ \text { DEQ }=\beta_{0}+\beta_{1} \text { SD_Quan }+\beta_{2} \text { SD_Qual }+\beta_{3} \text { Scale } \\ \text { IEQ } & \text { : Innate Earnings Quality } \\ \text { DEQ } & \text { : Discretionary Earnings Quality } \\ \text { SD_Quan } & \text { : Sustainability Disclosure Quantity } \\ \text { SD_Qual } & \text { : Sustainability Disclosure Quality } \\ \text { ROA } & \text { : Return on Assets } \\ \text { LEV } & \text { : Leverage } \\ \text { Scale_NOA } & \text { : Net Operating Assets per Sales } \\ \text { Op_Cycle } & \text { : Operating Cycle }\end{array}$

The quantity of sustainability disclosure is how many items of sustainability information are disclosed in the sustainability report. The measurement of sustainability disclosure quantity is based on the latest standard published by Global Reporting Initiatives, GRI G4. GRI G4 has two types of disclosures namely general and specific disclosures. General disclosure consists of seven parts, and specific disclosure consists of management approach and three performance indicators namely economic, environmental and social. Companies that disclose each item will be given a score of 1 while those who do not disclose will be given a score of 0 . The higher the number of scores, the higher the quantity of sustainability disclosure. Items disclosed by the company can be seen through the GRI index list of company sustainability reports.

The quality of sustainability disclosure is how management prepares a sustainability report. Measurement of the quality of sustainability disclosure uses three types of measurements, namely disclosure standards, the level of compliance and the presence or absence of assurance statements. Each report will be given a score based on criteria for the form and content of the report where the higher the total score obtained, the higher the quality of disclosure sustainability. The use of standards, the level of compliance and the availability of assurance statements can be identified through the status of the sustainability report on the GRI database website or can be directly checked in the company's sustainability report where it is explicitly disclosed in the sustainability report.

\section{Result and Discussion}

Determination of the sample used in this study uses a purposive sampling method in which obtained a number of 10 samples of agricultural and mining sub-sector companies listed on the Indonesia Stock Exchange in 2014 to 2018. There are 130 samples that meet the sample criteria. 


\subsection{Descriptive statistics}

Descriptive statistics of this study are presented in Table 2, which illustrates data through the average, maximum, minimum, and standard deviation values. In addition, this study also presented a graph of the development of sustainability disclosure in Indonesian agricultural and mining sub-sectors .

Table 3. Descriptive Statistics Test Results

\begin{tabular}{cccccc}
\hline & N & Minimum & Maximum & Mean & $\begin{array}{c}\text { Std. } \\
\text { Deviation }\end{array}$ \\
\hline IEQ & 130 & $-0,11$ & 0,035 & $-0,036$ & 0,037 \\
DEQ & 130 & $-0,095$ & 0,199 & $-0,005$ & 0,053 \\
SD_Quan & 130 & 0,26 & 0,814 & 0,504 & 0,148 \\
SD_Qual & 130 & 8 & 15 & 12,57 & 2,17 \\
ROA & 130 & $-6,86$ & 15,21 & 4,445 & 6,064 \\
LEV & 130 & 17,57 & 75,87 & 42,97 & 14,64 \\
Scale_NOA & 130 & 0,363 & 4,764 & 1,436 & 0,933 \\
Op_Cycle & 130 & 44,30 & 284,53 & 107,76 & 52,12 \\
Valid N & 130 & & & & \\
(listwise) & & & & & \\
\hline
\end{tabular}

The average of total sustainability disclosure of agriculture and mining sub-sector companies from 2014 to 2016 decreased. In 2014 the average total disclosure was 74,512 items from a maximum total of 150 items, decreased in 2015 to 73,200 items and in 2016 again decreased to 66,369 . When we viewed from the disclosure of each category, general information disclosure tends to be stable from 2014 to 2016. Disclosure of specific information on economic indicators also tends to be stable, but on environmental and social indicators has decreased from 2014 to 2018. Sustainability disclosure of companies in agriculture and mining sub-sectors in 2014 to 2018 it was still relatively low because on average it was still $47.2 \%$ of the information or items disclosed. This may be due to the voluntary disclosure nature of this sustainability report in Indonesia.

The average quality of sustainability disclosure of agriculture and mining sub-sector companies from 2014 to 2016 has increased. The quality of sustainability disclosure has increased from 12,300 to 12,500 in 2014, and has increased again in 2018 to 14,500 . Sustainability disclosure quality in agriculture and mining sub-sector companies in Indonesia is relatively high because it has reached an average overall quality score of 12,567 from a maximum score of 15 .

\subsection{T Test}

Two regression models were used. statistical t test results of each model can be seen in Tables 3 and 4. 
Table 4. Statistical t Test Results Regression Model 1

\begin{tabular}{|c|c|c|c|c|c|}
\hline \multirow[b]{2}{*}{ Model } & \multicolumn{2}{|c|}{$\begin{array}{c}\text { Unstandardized } \\
\text { Coefficients }\end{array}$} & \multicolumn{2}{|c|}{$\begin{array}{c}\text { Standardized } \\
\text { Coefficients }\end{array}$} & \multirow[b]{2}{*}{ Sig. } \\
\hline & B & Std. Error & Beta & $\mathbf{t}$ & \\
\hline (Contant) & $-0,158$ & 0,025 & & $-6,176$ & 0,000 \\
\hline SD_Quan & 0,040 & 0,019 & 0,175 & 2,340 & 0,025 \\
\hline SD_Qual & 0,005 & 0,001 & 0,282 & 3,505 & 0,002 \\
\hline $\mathrm{ROA}$ & 0,006 & 0,000 & 1,023 & 13,66 & 0,001 \\
\hline LEV & 0,002 & 0,001 & 0,095 & 1,312 & 0,208 \\
\hline
\end{tabular}

Table 5. Statistical t Test Results Regression Model 2

\begin{tabular}{|c|c|c|c|c|c|}
\hline \multirow[b]{2}{*}{ Model } & \multicolumn{2}{|c|}{$\begin{array}{l}\text { Unstandardized } \\
\text { Coefficients }\end{array}$} & \multirow{2}{*}{$\begin{array}{c}\begin{array}{r}\text { Standardized } \\
\text { Coefficients }\end{array} \\
\text { Beta }\end{array}$} & \multirow[b]{2}{*}{$\mathbf{t}$} & \multirow[b]{2}{*}{ Sig. } \\
\hline & B & Std. Error & & & \\
\hline 1 (Contant) & $-0,157$ & 0,025 & & $-6,176$ & 0,000 \\
\hline SD_Quan & 0,044 & 0,019 & 0,178 & 2,350 & 0,027 \\
\hline SD_Qual & 0,005 & 0,001 & 0,282 & 3,605 & 0,001 \\
\hline $\mathrm{ROA}$ & 0,006 & 0,000 & 1,023 & 13,65 & 0,000 \\
\hline LEV & 0,000 & 0,000 & 0,095 & 1,302 & 0,205 \\
\hline
\end{tabular}

\subsection{The Effect of Quantity Disclosure Sustainability on Innate Earnings Quality}

The results of hypothesis testing have stated that the quantity of sustainability disclosure has a positive effect on innate earnings quality (Table 3 sig ,0,05). Thus, the first hypothesis (H1) which predicts that the quantity of sustainability disclosure has a positive effect on innate earnings quality is accepted. The more quantity of sustainability disclosure will produce better Innate earnings quality. Conversely, a low quantity of sustainability disclosure will also result in poor earnings quality. The results of this study are consistent and support the theory of voluntary disclosure, signaling theory, and research conducted by Francis, Nanda, et al. (2008) [10], Kangarlouei et al. (2013) and Bona-Sánchez et al. (2017)[2].

The results of this study are in accordance with the voluntary disclosure theory, which states that companies tend to provide all relevant information related to economic performance, the environment, and compliance in order to ensure the functioning of the capital market is running well. Company information related to economic performance, the environment, and compliance is the source or form of innate earnings quality. The more quantity of sustainability information disclosed the company will encourage innate earnings quality or the quality of default earnings for the better. Later this will be captured and translated by the market as a good signal. The market will assess that the company has prospects for continued growth and development. This is similar to signaling theory that companies will give signals to the market with the aim of differentiating themselves from competitors. For example Petrosea Tbk increased the quantity of sustainability disclosure from 2015 by $32.67 \%$ to $40 \%$, which caused innate earnings quality to increase from 0.9506 to -0.6676 .

The results of this study support the research conducted by Francis, Nanda, et al. (2008) [10] which results that companies with good earnings quality have large voluntary disclosure compared to companies with worse earnings quality, where sustainability 
disclosure is part of voluntary disclosure. Similar research was carried out by Kangarlouei et al. (2013) which states that voluntary disclosure has a significant positive effect on earnings quality. Bona-Sánchez et al. (2017)[2] through his research entitled Sustainability Disclosure, Dominant Owners and Earnings Information, concludes that communication through sustainability reports will provide additional information to the market to assess earnings informativeness so it will reduce uncertainty and help interpret financial information better.

\subsection{The Effect of Quantity Disclosure Sustainability on Discretionary Earnings Quality}

Based on the results of hypothesis testing (table 4), it can be seen that the quantity of sustainability disclosure negatively influences discretionary earnings quality, which means that the greater the quantity of sustainability disclosure will affect discretionary earnings quality, the better, although these results are not significant and the hypothesis is rejected. The results of this study do not support the relation between voluntary disclosure theory and signaling theory with the disclosure of sustainability information and research conducted by Lee (2017)[16], Dhaliwal, Li, Tsang, \& Yang (2011)[16] and Ng \& Rezaee (2015) [20] but these results support research conducted by Verrecchia (1983)[24], Sengupta (2013)[21] and Shin \& Oh (2017)[22].

According to the voluntary disclosure and signaling theory theory, companies tend to disclose sustainability information and provide signals to the public with the aim of reducing information asymmetry between management and stakeholders so as to suppress the opportunistic behavior of management to present biased information. However, the results of this study, although sustainability disclosure has a positive effect on discretionary earnings quality, the effect is not significant as seen from the coefficient of -0.070 and a significance of 0.247 (table 5). This is because in this study, companies with an average quantity of sustainability disclosure below 0.5 or $50 \%$ and companies with an average quantity of sustainability disclosure above 0.5 or $50 \%$ have an average DEQ value that is not much different so differences in the influence of the number of disclosures on discretionary earnings quality are not too visible or insignificant.

Table 6. DEQ

\begin{tabular}{cc}
\hline $\begin{array}{c}\text { Sustainability Disclosure } \\
\text { Quantity }\end{array}$ & DEQ \\
\hline$<0,5$ or $<50 \%$ & 0,002034 \\
$>0,5$ or $>50 \%$ & $-0,001655$ \\
\hline
\end{tabular}

The results of this research support research conducted by Verrecchia (1983)[24] which states that voluntary disclosure and earnings quality have a substitutive relationship where extensive voluntary disclosure is associated with low earnings quality. A similar study was conducted by Shin \& Oh (2017)[22] who found that voluntary disclosure had a significant positive effect on information asymmetry resulting in lower discretionary earnings quality. This is strengthen by research (Crifo, Forget, \& Teyssier, 2015)[13] which found that investors more reacted to the practice of disclosure of bad sustainability than good. 


\subsection{The Effect of Sustainability Disclosure Quality on Innate Earnings Quality}

The results of hypothesis testing have stated that the quality of sustainability disclosure has a positive effect on innate earnings quality (Table 3 ). Thus, the third hypothesis (H3) which predicts that the quality of sustainability disclosure has a positive effect on innate earnings quality is accepted. That is, the higher the quality of sustainability disclosure will increase innate earnings quality. Conversely, a low quality sustainability disclosure will also reduce innate earnings quality. The results of this study are consistent and support the theory of voluntary disclosure and signaling theory and research conducted by Mouselli, Jaafar, \& Hussainey (2012)[18] , Jiao \& Francis (2015)[13], and Mohammadi (2017)[18].

The results of this study are consistent with voluntary disclosure theory, which states that companies tend to provide relevant information to attract stakeholder interest. Similarly, signaling theory states that companies try to differentiate themselves from competitors by giving a good signal to the market. In accordance with the statement of Short (2009)[23]., the quality of sustainability disclosure can affect the perceptions and behavior of investors and financial analysts, so the quality of sustainability disclosure becomes something that needs to be considered by management. According to the results of this third hypothesis test, it can be seen that the better the quality of the sustainability of corporate disclosure will increasingly improve the quality of corporate earnings (innate earnings quality). For example Elnusa Tbk improved the quality of sustainability disclosure from a score of 8 to 13 in 2016 by increasing the level of compliance disclosure so as to make innate earnings quality rise from -0.7078 to -0.66439 .

The results of this study support the research conducted by Mouselli et al. (2012)[19] who found a sustained relationship between accruals quality with disclosure quality, which means that accruals quality has a positive relationship with disclosure quality. The same thing was expressed by Jiao \& Francis (2015)[13] that there is a positive correlation between the quality of disclosure with future earnings forecasts. This result also supports the research of Mohammadi (2017)[18] which concluded that there is a relationship between the quality of disclosure and company performance in the present and the future.

\subsection{The Effect of Sustainability Disclosure Quality on Discretionary Earnings Quality}

Based on the results of hypothesis testing, it can be seen that the quality of sustainability disclosure has a positive effect on discretionary earnings quality (table 4). Thus, the fourth hypothesis (H4) which predicts that the quality of sustainability disclosure has a positive effect on discretionary earnings quality is accepted. The higher quality of sustainability disclosure will further increase discretionary earnings quality. Conversely, a low quality sustainability disclosure will also reduce discretionary earnings quality. These results are consistent and support agency theory and legitimacy theory and research conducted by Lobo (2001)[17] and Chamangard, Abadi, \& Janani (2013)[3].

According to agency theory, the setting of high standards for sustainability disclosure quality is intended as a monitoring and limitation for management in making reports so that it can reduce earnings management and overcome the problem of conflict of interest between agent and principal. By setting sustainability disclosure quality standards that are high increasingly, it is expected to be able to mitigate the opportunistic behavior of management so that earnings management is reduced and the quality of corporate earnings increases. According to legitimacy theory, companies that disclose high quality sustainability information tend to have moral motivation to comply with social values and norms so that it is less likely for companies to practice earnings management. For example PT Medco Energi Internasional Tbk improved the quality of sustainability disclosure in 
2015 with a score of 15 from 2014 of 13 which made the value of discretionary earnings quality decrease from 0.02717 to 0.05662 . The decline in the value of discretionary earnings quality illustrates the level of earnings management also decreases and discretionary earnings quality is getting better.

The results of this study support research conducted by Lobo (2001)[17] who found a negative relationship between disclosure quality and earnings management which means that the higher the quality of disclosure will suppress earnings management and increase discretionary earnings quality. Similar research results were also carried out by Chamangard, Abadi, \& Janani (2013)[3] which stated that the quality of disclosure has a negative relationship with earnings management which also means the higher the quality of disclosure will further suppress earnings management actions and vice versa the lower quality of disclosure will increase management opportunities to perform opportunistic behavior.

\section{Conclusion}

The quantity of sustainability disclosure has a significant positive effect on innate earnings quality. These results prove the company conducts sustainability disclosure in order to give a good signal to the market so that it can increase the innate earnings quality of the company. The quantity of sustainability disclosure does not have a significant positive effect on discretionary earnings quality. These results indicate that the flexibility of management to conduct sustainability disclosure does not affect the mitigation of earnings management practices as reflected by discretionary earnings quality. Sustainability disclosure quality has a significant positive effect on innate earnings quality. These results prove that the choice of sustainability disclosure quality influences the perceptions and behavior of stakeholders so as to increase the innate earnings quality of the company. Sustainability disclosure quality has a significant positive effect on innate earnings quality. These results prove that the choice of sustainability disclosure quality influences the perceptions and behavior of stakeholders so as to increase the innate earnings quality of the company. This research has a limitation : The test results of the coefficient of determination or Rsquare in the discretionary earnings quality model yields a result of $38.0 \%$ which results are still relatively low so it can be said that there are other factors outside this research model that can explain discretionary earnings quality. Future research are suggested to expand the use of expected variables influencing discretionary earnings quality to further clarify the model. For example variables related to company structure and compliance structure.

\section{Reference}

1. Bhattacharya, N., Desai, H., \& Venkataraman, K..Does Earnings Quality Affect Information Asymmetry? Evidence from Trading Costs. 30(2), 482- 516(2012)

2. Bona-Sánchez, C., Pérez-Alemán, J., \& Santana-Martin, D. J. Sustainability Disclosure, Dominant Owners and Earnings Informativeness. Research in International Business andFinance, 39,625-639. (2017)

3. Chamangard, A., Abadi, K., \& Janani, M. H. The Role of Disclosure Quality in Financial Reporting, 2(3), 439-443(2013)

4. Cohen, J., Holder-Webb, L., Nath, L., \& Wood, D. Corporate Reporting of NonFinancial Leading Indicators of Economics Performance and Sustainability. 1(26), 6590 (2012) 
5. Crifo, P., Forget, V. D., \&Teyssier, S. The price of environmental, social and governance practice disclosure: An experiment with professional private equity investors.30, 168-194 (2015)

6. Dhaliwal, D. S., Li, O. Z., Tsang, A., \& Yang, Y. G. Voluntary Nonfinancial Disclosure andtheCostofEquityCapital:TheInitiationofCorporateSocialResponsibilityReporting, 86(1), 59-100 (2011)

7. Dichev et al. Earnings Quality: Evidence from the Field, 25-27 (2013)

8. Dewan Standar Akuntansi Keuangan. (2009). PSAK No. 25 (revisi 2009): Kebijakan Akuntansi, Perubahan Estimasi Akuntansi, dan Kesalahan. Jakarta: Ikatan Akuntan Indonesia.

9. Francis, J., Olsson, P., \& Schipper, K. Earnings Quality, Foundation and Trends in Accounting(2008)

10. Francis, Nanda, \& Olsson. Voluntary Disclosure, Earnings Quality and Cost of Capital. 46(1), 53-99 (2008)

11. GRI. About Sustainability Reporting. Retrieved October 24, 2019, from https://www.globalreporting.org/information/sustainability-

Reporting/Pages/default.aspx (2018)

12. Ibrahim, M. S., Darus, F., Yusoff, H., \& Muhamad, R. Analysis of Earnings Management Practices and Sustainability Reporting for Corporations that Offer Islamic Products \& Services, 176-182 (2015)

13. Jiao, Y., \& Francis, B. Valuation , Corporate Disclosure, Market and Firm Performance,40(3), 647-676 (2015)

14. Kangarlouei, S. J., Rezaei, H., \&Motavassel, M. The investigation of the effect of voluntary disclosure on earnings quality and cost of capital in firms listed in Tehran Stock Exchange, 1(1), 1-6 (2013)

15. Laterdis, G., \& Alexkis, P. Evidence of Voluntary Accounting Disclosure in the Athens Stock Market. Retrieved from http://www.irawards.gr/gr/files/Iatridis_and_Alexakis_speeches.pdf(2010).

16. Lee, D. Corporate Social Responsibility and Management Forecast Accuracy. Journal of Business Ethics, (140), 353-367. (2017).

17. Lobo, G. J. Disclosure Quality and Earnings Management Disclosure Quality and Earnings Management Abstract. (2001).

18. Mohammadi, S,The Relationship between Disclosure Quality and Company Performances Using SPSS Software The Relationship between Disclosure Quality and Company Performances Using SPSS Software, (January), (2017)

19. Mouselli, S., Jaafar, A., \& Hussainey, K. (2012). Accruals Quality vis-à-vis Disclosure Quality: Substitutes or Complements? The British Accounting Review, 44(1), 36-46. https://doi.org/10.1016/j.bar.2011.12.004

20. Ng, A. C., \& Rezaee, Z. (2015). Business Sustainability Performance and Cost of Equity Capital. Journal of Corporate Finance. https://doi.org/10.1016/j.jcorpfin.2015.08.003(2015).

21. Sengupta, P, Corporate the Disclosure Cost of Debt, 73(4), 459-474, (2013)

22. Shin, H., \& Oh, H, The Effect Of Accruals Quality On The Association Between Voluntary Disclosure And Information Asymmetry In Korea, 33(1), 223-236, (2017)

23. Short, J. E,The Effect of Disclosures by Management, Analysts, and Business Press on Cost of Capital, Return Volatility, and Analyst Forecasts : A Study Using Content Analysis, 84(5), 1639-1670. (2009)

24. Verrecchia, Robert E. Discretionary disclosure. Journal of Accounting and Economics, 1983, vol. 5, issue 1, 179-194, 1983

25. https://davidparsaoran.wordpress.com/2009/11/04/skandal-manipulasi-laporan- 
keuangan-pt-kimia-farma-tbk/diakses 5 November 2018 